\title{
Landscape indicators as a tool of assessing landscape quality
}

\author{
Barbara Sowińska-Świerkosz ${ }^{1}$, Malwina Michalik-Śnieżek $^{2^{*}}$ \\ 1 Department of Hydrobiology and Ecosystems Protections, University of Life Sciences in Lublin, Dobrzańskiego 37, \\ Lublin 20-262, Poland, ORCID 0000-0002-0276-7809; e-mail: barbara.sowinska@wp.pl \\ 2 Department of Grassland and Landscape Shaping, University of Life Sciences in Lublin, Akademicka 13, Lublin 20- \\ 950, Poland; ORCID 0000-0002-4135-1531, e-mail: malwina.sniezek@up.lublin.pl
}

\begin{abstract}
Landscape quality (LQ) is understood as the state in which its (landscape) spatial, functional and visual structure is found at a given time. To measure this landscape characteristic different research methods and data types are needed including GIS techniques and remote sensing data as well as interviews and questionnaires, results of social perception studies, analysis of documents, registers and statistical data, landscape visual studies and 3D drawings. Presented study aims to fully analyze the LQ of the Roztocze region based on above mentioned methods. To do so, the categorization of 24 quantitative indices was applied. Results indicated high structural and ecological values, medium visual values and values of spatial harmony and low cultural and perceptual properties of analyzed area. The study results also showed the great importance of spatial data and GIS techniques in LQ assessment.
\end{abstract}

\section{Introduction}

Landscape indicators are defined as indexes that allowed to determine landscape character and its social perception based on numerical values, allowing a large number of data to be reduced to a simple objective measure $[1,2]$. Different indices are commonly used to assess various characteristic of landscape such as configuration and structure of land cover categories, ecological values, visual and cultural features, social perception and changes in time $[3,4]$ These spatial and non-spatial characteristics determines the level of landscape quality (LQ) of a given area. LQ is understood as the state in which its (landscape) spatial, functional and visual structure is found at a given time [5]. To fully assess LQ different kinds of methods and data types are needed, including GIS techniques, remote sensing data, interviews, questionnaires, results of social perception studies, analysis of documents, register and statistical data, landscape visual studies and 3D drawings as well as in-situ studies and data on ecological state and biodiversity [6]. Such interdisciplinary studies, however, are the rarity as most papers which have been published so far focused on one or two dimension of LQ by the use of limited types of data and techniques.

To fill this gap, presented paper aims to fully analyze the landscape quality of the part of Roztocze region (south-east part of Poland) based on the application of diverse research methods and data types. As test area was selected Roztocze National Park (NP) together with its buffer zone (Fig. 1).

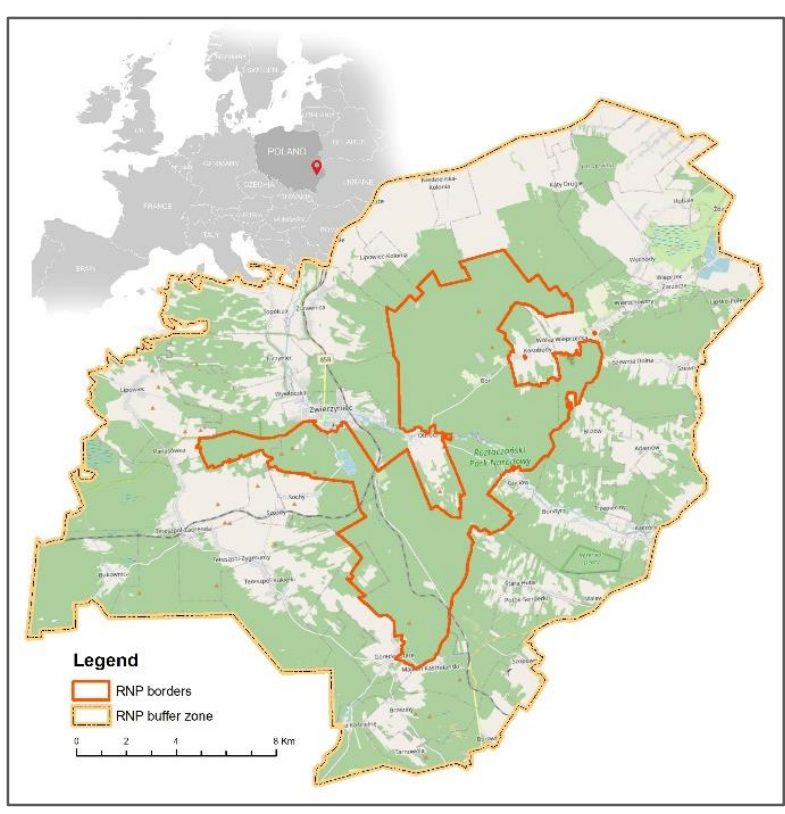

Fig. 1. Location of the study area and the system of protected areas (RNP - Roztocze National Park)

\section{Materials and methods}

To fully analyze LQ four research methods and six general data types were used (Table 1). GIS analysis was based on the application of ArcGIS 10.5.1 software and national spatial databases such as Numerical Terrain Model (NTM grid interval of at least $100 \mathrm{~m})$, Database of topographic objects [7], Orthophotomap [8]. Sociological research includes (1) 
application of questionnaire and (2) the assessment of social preferences based on the use of landscape photographs assessed on a 5-point scale $(1=$ like the least; $5=$ like the most). The group of 120 respondents took part in the research including farmers, tourists, experts and students. Landscape visual studies were based on the analysis of 16 landscape scenes illustrating characteristic features of the region. Positive and negative landscape elements were indicated and their percentage share were calculated. Meta-analysis of documents and registers included: spatial local plans, protection plans of Roztocze National Park and NATURA 2000 sites, register of cultural monuments.

Table 1. Research method and data types applied in the study

\begin{tabular}{|c|c|}
\hline Method & Data type \\
\hline GIS techniques & $\begin{array}{c}\text { Spatial (vector and raster } \\
\text { formats) }\end{array}$ \\
\hline Sociological research & Descriptive and statistical \\
\hline $\begin{array}{c}\text { Landscape visual studies } \\
\text { Landscape scenes, panoramas } \\
\text { photographs, drawings }\end{array}$ \\
\hline $\begin{array}{c}\text { Metanalysis of documents } \\
\text { and registers }\end{array}$ & Descriptive and statistical \\
\hline
\end{tabular}

Based on different data sources a spatial database was elaborated. The main layer for calculation of most of the indices, was the Database of topographic objects [7] updated - based upon the Orthophotomap [8]. Then, a set of 24 landscape indicators was calculated to conclude on LQ of the analyzed area (Table 2). Structural characteristics were based on the result of landscape metrics, which describe the structure and configuration of land cover (LC) forms. Metrics were calculated by the use of Fragstats software. Assessment of spatial harmony was based on the use of indicators applied in rural planning. They deal with accessibility criteria $[9,10]$ and urban sprawl measurements [11]. Indicators PROTAP and HLE were based on the national register of monuments (Geospatial service of Monuments). As historical landscape elements were treated historical parks, gardens and avenues of trees. ECOLBAR and MSDI were calculated based on the methodology presented by Sowińska-Świerkosz [12]. As ecological barriers were treated only fragments of paved roads and railways crossing natural and semi-natural land cover forms. MSDI index is based on the application of Shannon Diversity Index multiplied by the variable which takes into account the ecological significance of LC forms ( 1 for natural LC forms, 0.75 for seminatural, 0.5 for anthropogenic LC forms containing water and greenery, 0 for built-up areas and paved surfaces). In the visual quality assessment as positive landscape elements were treated: water, natural and semi-natural forms of vegetation, positive man-made structures, and as negative disharmonious anthropogenic objects. Such approach is consistent with the results of many other studies dealing with landscape preferences analysis $[13,14,15]$. In the study were analyzed landscape scenes applied in Sowińska-Świerkosz and Soszyński [16] in relation to the Roztocze region. Indexes of social perception were based on the mean values ascribed by respondents to 16 landscape scenes presented in photographs, and on mean values ascribed to characteristic landscape features presented within test area (based on the structural questionnaire).

The study has a staged character and includes research conducted in years 2014-2019. Partial results of the study has been published in Sowińska-Świerkosz and Chmielewski [17]; Sowińska-Świerkosz and Soszyński [16]; Sowińska-Świerkosz and MichalikŚnieżek [5]. Results of spatial harmony indicators and visual values together with the total results are published for the first time.

Table 2. Indicators used in the research

\begin{tabular}{|c|}
\hline Indicator name \\
\hline Structural characteristics \\
\hline Patch Richness (PR) \\
\hline Percentage of landscape (PLAND/\%) \\
\hline Mean Patch Area (MPA $\left./ \mathrm{km}^{2}\right)$ \\
\hline Edge Density $\left(\mathrm{ED} / \mathrm{m} / \mathrm{m}^{2}\right)$ \\
\hline Contagion Index (CONTAG) \\
\hline Spatial harmony \\
\hline Percentage coverage with local plans (PLANSHARE) \\
\hline $\begin{array}{l}\text { Mean distance between closest villages along paved } \\
\text { roads (MEAN VILLAGE } / \mathrm{km} \text { ) }\end{array}$ \\
\hline $\begin{array}{l}\text { Mean distance between centers of villages and } \\
\text { communal village along paved roads (MEAN }\end{array}$ \\
\hline CENTRAL $/ \mathrm{km})$ \\
\hline Transportation routes density (TRANS DENSITY), \\
\hline Mean size of villages (VILLAGE SIZE $/ \mathrm{km}^{2}$ ) \\
\hline Share of disperse settlement (DISPERSESETTEL/\%) \\
\hline $\begin{array}{l}\text { Share of complex settlement } \\
\text { (COMPLEXSETTEL/\%) }\end{array}$ \\
\hline Ecological state \\
\hline $\begin{array}{l}\text { Density of ecological barriers (ECOLBAR/ km/ } / \mathrm{km}^{2} \text { ) } \\
\text { Modified Shannon Diversity Index (MSDI) }\end{array}$ \\
\hline Cultural heritage values \\
\hline $\begin{array}{c}\text { Density of historical monuments (PROTAP/ km/ } / \mathrm{km}^{2} \text { ) } \\
\text { Historical landscape elements (HLE/\%) }\end{array}$ \\
\hline Visual values \\
\hline $\begin{array}{l}\text { Share of positive land cover forms (PLCF/\%) } \\
\text { Share of negative land cover forms (NLCF/\%) }\end{array}$ \\
\hline Social perception \\
\hline $\begin{array}{l}\text { Mean value of total assessment of landscape scenes } \\
\text { (TOTALPERC) }\end{array}$ \\
\hline $\begin{array}{c}\text { Mean value given to characteristic upland landscape } \\
\text { (RELIEFPERC) }\end{array}$ \\
\hline Plentiful springs and clean rivers (WATERPERC) \\
\hline $\begin{array}{c}\text { Vast complexes of diverse natural forests } \\
\text { (FORESTPERC) }\end{array}$ \\
\hline $\begin{array}{l}\text { Small area rural and provincial colonization } \\
\text { (SETTELMENTPERC) }\end{array}$ \\
\hline Historical urban-landscape structure (HISTPERC) \\
\hline
\end{tabular}




\section{Results}

Results of landscape metrics indicate that the Roztocze NP together with its buffer zone features the highest value of PLAND in the case of coniferous forest (34.42\%) (Table 3). Values of MPA (18.6), ED (83.28) and CONTAG (69.71) (CONTAG approaches to 100 shows that all patch types are maximally aggregated) showed rather compact structure of land cover (LC) forms of the analyzed area, especially while comparing with other national parks in Poland [5]. It derives from the fact that in the LC structure of the Roztocze region predominate the large surface patches, mainly of forest of different types.

Table 3. Results of indicators calculation

\begin{tabular}{|c|c|}
\hline Indicator name & Indicator value \\
\hline $\mathrm{PR}$ & 11 \\
\hline PLAND & $34.42 \% *$ \\
\hline MPA & $18.6 \mathrm{~km}^{2} *$ \\
\hline ED & $83.28 \mathrm{~m} / \mathrm{m}^{2 *}$ \\
\hline CONTAG & $69.71 *$ \\
\hline PLANSHARE & $28.6 \%$ \\
\hline MEANVILLAGE & $3.35 \mathrm{~km}$ \\
\hline MEANCENTRAL & $9.95 \mathrm{~km}$ \\
\hline TRANSDENSITY & $1.89 \mathrm{~km} / \mathrm{km}^{2}$ \\
\hline VILLAGESIZE & $0.37 \mathrm{~km}^{2}$ \\
\hline DISPERSESETTEL & $24 \%$ \\
\hline COMPLEXSETTEL & $76 \%$ \\
\hline ECOLBAR & $2.81 \mathrm{~km} / \mathrm{km}^{2} *$ \\
\hline MSDI & $0.79 *$ \\
\hline PROTAP & $0.09 \mathrm{~km} / \mathrm{km}^{2} *$ \\
\hline HLE & $0.002 \% *$ \\
\hline PLCF & $38.19 \%$ \\
\hline NLCF & $7.96 \%$ \\
\hline TOTALPERC & $3.39 * * *$ \\
\hline RELIEFPERC & $3.60 * *$ \\
\hline WATERPERC & $3.59 * *$ \\
\hline FORESTPERC & $4.00 * *$ \\
\hline SETTELPERC & $2.92 * *$ \\
\hline HISTPERC & $3.80 * *$ \\
\hline
\end{tabular}

*Based on Sowińska-Świerkosz and Michalik-Śnieżek [5]; **Based on Sowińska-Świerkosz and Chmielewski [17]; ***Based on Sowińska-Świerkosza and Soszyński [16]

Spatial harmony indicators showed that only $28.6 \%$ of the study area (PLANSHARE) is covered by local spatial plans, being non obligatory tool of spatial planning in Poland. This tool, however, is the only one which can ensure the harmonious development of any area. Values of MEANVILLAGE $(3.35 \mathrm{~km})$ together with MEANCENTRAL $(9.95 \mathrm{~km})$ indicate medium accessibility between villages of different functions. Besides, the density of transportation routes (TRANSDENSITY $=1.89 \mathrm{~km} / \mathrm{km}^{2}$ ) is much lower than the average value for the country which is $86 \mathrm{~km} / \mathrm{km}^{2}$. It derives from the fact that $76 \%$ of the test area is covered by natural LC forms and about $20 \%$ is under the national park protection. The spatial characteristic of villages indicates rather complex settlements structure $(\mathrm{COMPLEXSETTEL}=76 \%)$ of mean villages' area equals to $0.37 \%$ being lower than the average for Poland.

The analysis of the indicators describing the ecological state showed that the density of ecological barriers is quite low (2.81). It is a result of the applied method: as ecological barriers were treated only fragments of paved roads and railways crossing natural and semi-natural land cover forms which predominate in the structure of the analyzed area. It may be concluded that ecological barriers have a low negative impact on the species movement and the continuity of ecological processes inside analyzed area [5]. Index MSDI possess quite high values -0.79 (maximum is 1.00) testifying that the landscape of Roztocze NP and its buffer zone is mostly covered by natural land cover forms which distribution is perfectly even.

Cultural heritage values, based on PROTAP and HLE indicators, occurred to be very low -0.09 and 0.002 respectively. Despite the fact that there are 43 heritage monuments included in national register (mainly located in one city of Zwierzyniec) their area is very small. The lack of culturally important built heritage in the rest of the area resulted from the fact that NP was for many years excluded from human activities [5].

Visual values of the Roztocze region occurred to be on medium level. About 38\% (PLCF) of the area of analyzed 16 landscape scenes are covered by elements classified as having positive impact on visual LQ. Only $8 \%$ of LC forms was of negative character. The later includes paved roads, disharmonious forms of settlement and electric poles.

Total perception of visual values of analyzed area is at average level as the mean value given by all the respondents equals to 3.39 (5 is maximum) [17]. It results from the fact that all types of landscape scenes presented within the test area, including built-up areas and roads, were judged by the respondents. While including scenes composing of only natural and seminatural structures and constituting $76 \%$ of the test area, TOTALPERC equals to 4.21 . The clear differences in the respondents opinion between built-up areas and natural/semi-natural areas are also seen while analyzing values ascribing to characteristic features of the region. Index SETTELPERC is significantly lower than indicators related relief structure, water bodies, forest complexes and even historical structures. Among them, index referring to the presence of vast complexes of diverse natural forests (FORESTPERC) is of the highest score (4.00) (Fig.2). 


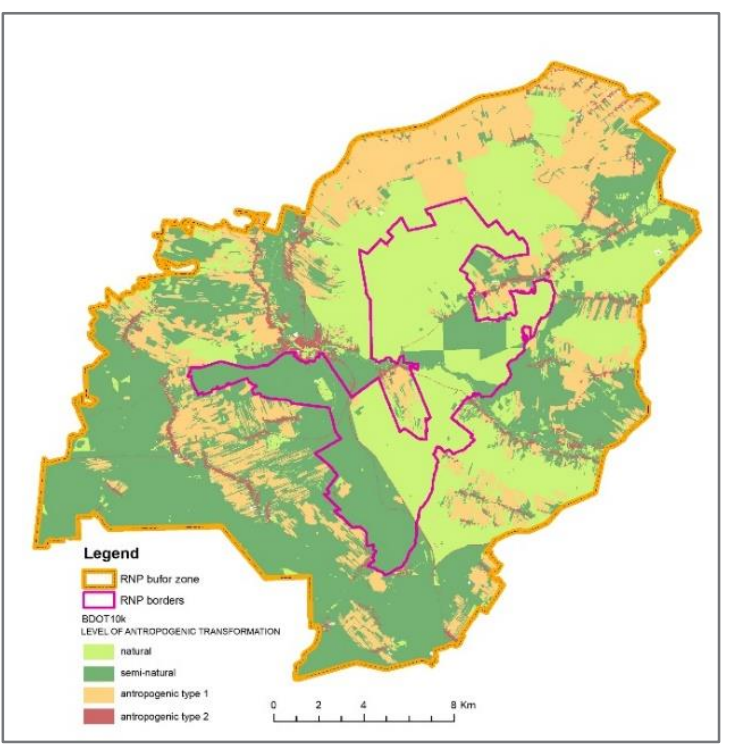

Fig 2. Share of natural, semi-natural and anthropogenic land cover form within test area (based on BDOT data updated based upon ortophotomap from 2019)

Taken into account different data sources, the conducted study showed that the most important was the use of spatial data and the application of GIS techniques (Fig. 3). These method allowed to calculate 18 of 24 analyzed indices (75\%). Spatial data was crucial in the case of LQ dimensions referring to the structural characteristics as well as to the most aspects of spatial harmony. GIS was also valuable source of cultural and visual data. Analysis of documents and registers was used to assess indicators related to ecological and cultural heritage - 5 indices (21\%). Sociological studies were indispensable to measure social perception, based on the results of landscape scenes assessment and questionnaire application -6 indices $(25 \%)$. Landscape visual studies were used to assess 2 indices related to visual quality assessment $(8 \%)$.

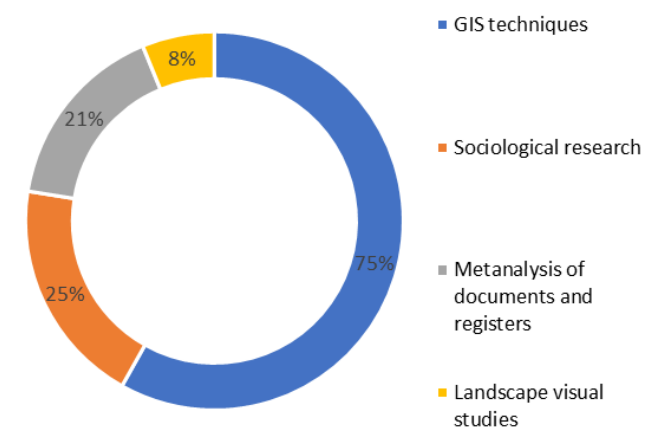

Fig 3. The usefulness of different research methods in the assessment of LQ of the analyzed area

\section{Discussion}

Total research results - indicates high structural and ecological values of analyzed areas. This finding has been reported by other researchers $[6,12,17,5]$. It derives from the character of the test area: national parks are delineated due to the outstanding ecological and landscape values and, in most of the cases, due to the protected actions, they (values) are preserved for the long time [18]. Quite surprising outcome are low cultural heritage values. It results from the application of indices based on only tangible cultural heritage. The concept of cultural heritage, however, includes also intangible values such as practices, places, objects, artistic expressions and values [19], as well as subjective variables such as familiarity and nostalgia [20]. The lack of this dimension is the shortcoming of applied method, indicating that next studies dealing with LQ analysis should include also intangible measures. Spatial harmony indices showed rather low accessibility regarding to main functions of the most of the villages located within the test area. The low density of transportation routes is the main problem here. Complex settlements structure, however, indicated low level of fragmentation and sustainable development of the test area [11]. Perceptual values of the Roztocze region occurred to be divided respectively on the analyzed features: natural/seminatural LC forms versus man-made structures. The latter was judged significantly lower, as presumably most of the respondents identify the concept of national park as an area of the natural state. Therefore, any form of built-up areas, including small scale rural and provincial colonization, was perceived as of negative impact on LQ. The same applies to the visual values. The share of positive landscape elements were significantly higher (46.87) in the case of scenes covering only water and greenery than of scenes including structures typical for built-up areas (27.03). It showed that most of the man-made structures of the Roztocze region has a negative impact on visual values.

The study results also showed the great importance of spatial data and GIS techniques in LQ assessment. These finding is consistent with other research aiming at the assessment of different levels of LQ based on GIS techniques including: cultural values [21,22], visual dimension $[6,23]$, ecological sphere $[12,24]$ and spatial harmony $[25,26]$. To fully examine the issue of LQ assessment, however, next to spatial data should be used non-spectral ones referring to the indication of places of high values to the general public together with the meta-analysis of registers and local documents.

\section{Conclusions}

Conducted research allowed to conclude on the level of LQ of the Roztocze region based on application of 24 quantitative indicators. The results showed that:

1. The research area have high structural and ecological values, medium visual and spatial harmony values and low values of cultural heritage.

2. The application of spatial data and GIS techniques is necessary to analyze different dimensions of LQ 
3. Non-spectral data are needed to analyzed perceptual and visual aspects of LQ and are helpful in the case of ecological and cultural ones.

\section{Acknowledgements}

Publication is funded by the Polish National Agency for Academic Exchange under the International Academic Partnerships Program from the project „Organization of the 9th International Scientific and Technical Conference entitled Environmental Engineering, Photogrammetry, Geoinformatics - Modern Technologies and Development Perspectives.

\section{References}

1. Swetnam, R.D.; Tweed, F.S. A tale of two landscapes: Transferring landscape quality metrics from Wales to Iceland. Land Use Policy (2018); 76, pp. 565-576.

2. Cassatella, C.; Peano, A. (Eds.). Landscape Indicators. Assessing and Monitoring Landscape Quality. Springer (2011), Dordrecht-HeidelbergLondon-NewYork.

3. Santé, I.; Fernández-Ríos, A.; Tubío, J.M.; GarcíaFernández, F.; Farkova, E.; Miranda, D. The Landscape Inventory of Galicia (NW Spain): GISweb and public participation for landscape planning. Land Res. (2018), 44, 212-240.

4. Vizzari, M. Spatial modelling of potential landscape quality. Appl. Geogr. (2011), 31, 108118.

5. Sowińska-Świerkosz, B; Michalik-Śnieżek, M. The Methodology of Landscape Quality (LQ) Indicators Analysis Based on Remote Sensing Data: Polish National Parks Case Study. Sustainability (2020), 12(7), 2810; https://doi.org/10.3390/su12072810

6. Sowińska-Świerkosz, B.; Chmielewski, T.J. A new approach of the identification of Landscape Quality Objectives (LQOs) as a set of indicators. J Environ. Manag. (2016)., 184, pp. 596-608.

7. Database of Topographic Objects Available online: http://www.gugik.gov.pl/strona-glowna (accessed on 10 December 2019).

8. Ortofotomapa. Available online: http://www.gugik.gov.pl/pzgik/zamowdane/ortofotomapa (accessed on 10 December 2019).

9. Borzacchiello, M.T., Nijkamp, P., Koomen, E., Accessibility and Urban Development: A GridBased Comparative Statistical Analysis of Dutch Cities. Environment and Planning B: Planning and Design. (2010) DOI: 10.1068/b34126

10. Wolf, T., Meyer, B.C. Suburban scenario development based on multiple landscape assessments. Ecological Indicators (2010), 10 (1), pp.74-86

11. Cabrera-Jara, N.; Orellana, D., Hermida M.A. Assessing sustainable urban densification using geographic information systems. INTERNATIONAL JOURNAL OF SUSTAINABLE Building Technology and Urban Development. (2017), 8(2), pp. 237-243.

12. Sowińska-Świerkosz, B. Review of cultural heritage indicators: types, categorisation schemes and their usefulness in landscape quality assessment. Ecol. Indic. (2017); 81, pp. 526-542.

13. Arriaza, M., Cañas-Ortega, J.F., Cañas-Madueno, J.A., \& Ruiz-Aviles, P. Assessing the visual quality of rural landscapes. Landscape and Urban Planning, (2004), 69, pp. 115-125.

14. Bulut, Z., \& Yilmaz, H. Determination of landscape beauties through visual quality assessment method: a case study for Kemaliye. Environmental Monitoring and Assessment, (2008), 141, pp.121-129.

15. Howley, P. Landscape aesthetics: Assessing the general publics' preferences towards rural landscapes. Ecological Economics, (2011),72, pp.161-16.

16. Sowińska-Świerkosz, B.; Soszyński, D. The index of the Prognosis Rural Landscape Preferences (IPRLP) as a tool of generalizing peoples' preferences on rural landscape. J. Environ. Manag. (2019); 248, pp. 109272.

17. Sowińska-Świerkosz, B.; Chmielewski, T.J. Comparative Assessment of Public Opinion on the Landscape Quality of Two Biosphere Reserves in Europe. Environ. Manag. (2014); 54; pp. 531-556.

18. Amaral, Y.T.; Santos, E.M.D.; Ribeiro, M.C.; Barreto, L. Landscape structural analysis of the Lençóis Maranhenses national park: Implications for conservation. J. Nat. Conserv. 2019, 51, 125725.

19. ICOMOS, International Cultural Tourism Charter. Principles And Guidelines For Managing Tourism At Places Of Cultural And Heritage Significance. ICOMOS International Cultural Tourism Committee. (2002).

20. Ginting, N., Wahid, J. Exploring identity's aspect of continuity of urban heritage tourism. Procedia Soc. Behav. Sci. (2015), 202,pp. 234-241. http://dx.doi.org/10.1016/j. sbspro.2015.08.227

21. Nahuelhual, L., Carmona, A., Laterra, P., Barrena, J., Aguayo, M., 2014. A mapping approach to assess intangible cultural ecosystem services: the case of agriculture heritagein Southern Chile. Ecol. Indic. 40, 90-101. http://dx.doi.org/10.1016/j.ecolind.2014.01.005.

22. Pert, P.L., Hill, R., Maclean, K., Dale, A., Rist, P., Schmider, J., Talbot, L., Tawake, L., 2015. Mapping cultural ecosystem services with rainforest aboriginal peoples: integrating biocultural diversity, governance and social variation. Ecosys. Serv. 13,41-56. http://dx.doi.org/10.1016/j.ecoser.2014.10.012

23. Han, F., Yang, Z., Liu, X., Di, F., 2011. Impact assessment and protection of outstanding landscape integrity in a natural heritage site: Fairy 
Valley, KanasNature Reserve, Xinjiang, China. J. Mt. Sci. 8, 46-52.

24. Uuemaa, E., Antrop, M., Roosaare, J., Marja, R., Mander, U., 2009. Landscape metricsand indices: an overview of their use in landscape research. Living Rev. Landsc.Res. 3, http://dx.doi.org/10.12942/lrlr-2009-1.

25. La Rosa, D., Privitera, R., Martinico F., La Greca P. Measures of safeguard and rehabilitation for landscape protection planning: a qualitative approach based on diversity indicatorset. Journal of Environmental Management. (2013), pp.73-83 DOI: 10.1016/j.jenvman.2012.12.033

26. Almenar, J. B., Boliwich, A., Eliot, T., Geneletti D., Sonnemann, G. Assessing habitat loss, fragmentation and ecological connectivity in Luxembourg to support spatial planning. Landscape and Urban Planning. (2019), 189, pp. 335-351. DOI: 10.1016/j.landurbplan.2019.05.004 